\title{
POLSKI JĘZYK HUMANISTYCZNY DLA CUDZOZIEMCÓW MNIEJ I BARDZIEJ ZAAWANSOWANYCH
}

\begin{abstract}
Słowa kluczowe: język specjalistyczny, polski język humanistyczny, cechy, teksty, terminologia, składnia

Streszczenie. Autorka, biorąc pod uwagę zadania, przed jakimi stają studenci obcokrajowcy studiujący na polskich uniwersytetach, podejmuje próbę omówienia wspólnych dla różnych nauk humanistycznych właściwości językowych, decydujących o specyfice humanistycznej odmiany języka polskiego. Zwraca uwagę na cechy języka humanistycznych tekstów akademickich oraz popularnonaukowych (obiektywizm, intelektualizm czy depersonalizacja) i omawia środki językowe, za pomocą których się je tworzy. Wskazuje na zagadnienia językowe, z jakimi powinni zapoznać się cudzoziemcy zamierzający studiować w Polsce. Wskazuje też źródła tekstów do pracy ze słuchaczami kursów języka specjalistycznego - od podręczników akademickich (dla najbardziej zaawansowanych), poprzez teksty prasowe i internetowe, do podręczników dla cudzoziemców.
\end{abstract}

\section{WPROWADZENIE}

Prezentowana poniżej koncepcja nauczania języka polskiego jako obcego w odmianie humanistycznej powstała w Studium Języka Polskiego dla Cudzoziemców Uniwersytetu Łódzkiego. Tworzona była przede wszystkim z myślą o tych osobach, które w SJPdC zaliczyły I semestr nauki (w grupie o profilu humanistycznym obejmujący około 300 godzin języka polskiego i około 100 godzin tzw. przedmiotów kierunkowych, takich jak historia, geografia czy wiedza o Polsce), osiągnęły poziom co najmniej A2+ (preferowanym poziomem wyjściowym jest B1) i zamierzają w niedalekiej przyszłości studiować na kierunkach

*gaja@toya.net.pl; Studium Języka Polskiego dla Cudzoziemców, Uniwersytet Łódzki, 90231 Łódź, ul. Jana Matejki 21/23. 
humanistycznych. $Z$ naszych wieloletnich obserwacji wynika, że zainteresowania słuchaczy grup humanistycznych są szerokie i zróżnicowane, a ich potrzeby językowe nie są tak precyzyjnie określone jak potrzeby przyszłych medyków czy ekonomistów. Biorąc pod uwagę fakt, że język specjalistyczny służy do przekazywania wiedzy z konkretnej dziedziny i zwykle jest używany przez stosunkowo wąską grupę zajmujących się daną dziedziną osób, to w przypadku języka humanistów dziedzin tych jest wiele, a grupa zainteresowanych nimi specjalistów jest liczna i niejednorodna. Dla nauczyciela idealna byłaby sytuacja, kiedy to w jednej grupie językowej uczyliby się przyszli prawnicy, w innej - pedagodzy, a jeszcze w innej - filolodzy czy artyści. W praktyce jednak tworzenie jedno-, dwu- czy nawet czteroosobowych grup jest trudne i zwykle, głównie z przyczyn ekonomicznych, niemożliwe. Zatem nauczyciel, uczący humanistów o różnorodnych zainteresowaniach, musi brać pod uwagę, wspólny dla nich wszystkich, nadrzędny cel, dla którego zdecydowali się na naukę języka polskiego. Celem tym są studia humanistyczne w Polsce. Nauczyciel jpjo na roku „0” musi więc wyposażyć słuchaczy w narzędzia językowe umożliwiające im:

- po pierwsze, funkcjonowanie w środowisku akademickim, w którym znajdą się w różnych sytuacjach komunikacyjnych i przyjdzie im odgrywać różne role społeczne - kolegi, współlokatora, sąsiada i tutaj może wystarczyć znajomość języka ogólnego;

- po drugie, występowanie w funkcji petenta, więc potrzebna jest znajomość urzędowo-kancelaryjnej odmiany języka, umiejętność czytania pism urzędowych i formularzy, umiejętność redagowania pism użytkowych (ogłoszenie, podanie, skarga, reklamacja, umowa) i prowadzenia korespondencji urzędowej;

- $\quad$ po trzecie, najważniejsze - słuchacze znajdą się w roli studentów - będą uczęszczać na wykłady i ćwiczenia, wymagać się będzie od nich korzystania z różnorodnych tekstów akademickich: podręczników i skryptów, encyklopedii i słowników, artykułów, wywiadów, recenzji, monografii. Aby sprostać temu zadaniu muszą poznać naukową odmianę języka polskiego, w tym wypadku odmianę humanistyczną.

Zakładając, za autorami pozycji Języki specjalistyczne. Słownik terminologii przedmiotowej (Lukaszyn, Górnicz 2005), że język ogólny stanowi bazę, dla korzystających z jego fonetyki i gramatyki, języków specjalistycznych i że żaden język specjalistyczny nie jest ani kompletny ani samodzielny bez języka ogólnego, za podstawę nauczania $\mathrm{w}$ grupach humanistycznych na poziomach od B1 do $\mathrm{C} 1 \mathrm{w}$ omawianej koncepcji przyjmuje się właśnie język ogólny, jakim posługuje się większość, posiadających przynajmniej średnie wykształcenie, Polaków. Przeważającą liczbę zagadnień gramatycznych realizuje się zgodnie z ogólnymi wytycznymi programów nauczania i obowiązującymi standardami kształcenia dla 
odpowiedniego poziomu znajomości języka. Zwraca się jednak szczególną uwagę na te zagadnienia, które decydują o specyfice specjalistycznej - w tym wypadku humanistycznej - odmiany języka, wpływają na jego precyzję, obiektywizm, depersonalizację, substantywizację (Sawicka 2009, s. 197), a w przypadku języka prawa - także na nakazowość.

A. Wilkoń zauważył, że współcześnie „w naukach humanistycznych zarysowała się dobitnie dążność do nadania im charakteru dyscyplin ścisłych, wyrażająca się między innymi w zastosowaniu metod ilościowych, wzorców matematycznych, ścisłej terminologii, suchego stylu referencjalnego. (...) W języku współczesnej humanistyki dominuje bezstylowy wzorzec relacji zobiektywizowanej, bogatej w formy nieosobowe, zupełnie nieomal pozbawionej elementów subiektywno-ekspresywnych i estetycznych" (Wilkoń 1987, s. 74). Można by nawet zaryzykować stwierdzenie, że specjalistyczny język współczesnej humanistyki upodobnił się do języka nauk ścisłych. Potwierdzają to badania S. Mikołajczyka, który stosując metody matematyki i statystyki, dokonał analizy porównawczej języka humanistycznych tekstów naukowych i popularnonaukowych oraz języka tekstów literackich.

Przedmiotem naszego zainteresowania w niniejszym artykule są jedynie dwa pierwsze rodzaje tekstów. Nie oznacza to, że słuchacze łódzkiego SJPdC nie stykają się na zajęciach z tekstami literackimi, znaczy jedynie, że język literacki nie jest $\mathrm{w}$ nim przedmiotem oglądu, a jego specyfika omawiana jest w odrębnych opracowaniach. Z tych samych powodów pominęliśmy omówienie właściwości języka prawniczego. Koncentrujemy się na opisie cech specyficznych, a zarazem wspólnych dla języka wybranych dziedzin humanistyki: historii, filozofii, pedagogiki, socjologii, językoznawstwa, kulturoznawstwa. Pamiętamy o tym, że język specjalistyczny w odmianie akademickiej, którą wdrażamy na kursach językowych w sprofilowanych grupach cudzoziemskich, służy do opisu konkretnego, węższego obszaru wiedzy i jest używany przez specjalistów w jednej z wyżej wymienionych dziedzin humanistyki, jakimi chcą stać się w niedalekiej przyszłości uczący się w SJP cudzoziemcy. Język tekstów akademickich nasycony jest terminologią i strukturami składniowymi właściwymi dla konkretnych nauk humanistycznych. Studenci zapoznają się z nimi podczas lektury wybranych przez nauczyciela tekstów i utrwalają je dzięki odpowiednio opracowanym ćwiczeniom leksykalno-gramatycznym. Prezentowane słuchaczom, obok tekstów akademickich, teksty popularnonaukowe, to teksty kierowane do szerszego grona odbiorców - niespecjalistów i jako takie, są bardziej przystępne, łatwiejsze w odbiorze dla Polaków, ale niekoniecznie dla obcokrajowców. Teksty te są barwniejsze niż teksty naukowe, zawierają mniej - znanych studentom - terminów fachowych, a więcej - nie zawsze im znanych - zwrotów potocznych. Ekspresywność i nasycenie metaforyką są często utrudnieniem dla osób mniej zaawansowanych językowo. Dlatego takie teksty powinny być uzupełniane ćwiczeniami frazeolo- 
gicznymi. Nie jest jednak naszym celem porównywanie tekstów akademickich i popularnonaukowych. Interesuje nas to, co je łączy - wspólne dla nich zjawiska językowe. Nauczyciel, wybierając na zajęcia teksty dydaktyczne - zarówno te naukowe, jak i popularnonaukowe - zwraca uwagę na informacje merytoryczne dotyczące danej dziedziny wiedzy oraz na zawarty w nich materiał językowy.

\section{ZJAWISKA JEZZYKOWE W HUMANISTYCZNYCH TEKSTACH NAUKOWYCH I POPULARNONAUKOWYCH}

Humanistyczne teksty naukowe i popularnonaukowe powinny posługiwać się właściwą dla tej dziedziny leksyką (terminologią) i prezentować odpowiednie struktury składniowe, których opanowanie ułatwi słuchaczom pracę podczas przyszłych studiów. Opisując język naukowych i popularnonaukowych tekstów humanistycznych, skupimy się więc na właściwej dla nich składni, związkach frazeologicznych (powtarzających się w obu rodzajach tekstów), łączliwości składniowej, a także na specjalistycznej terminologii.

S. Mikołajczyk charakteryzując styl naukowy, w tym również styl tekstów humanistycznych, przypisuje mu cechy takie jak: abstrakcyjność, intelektualność, logiczność, pojęciowość, obiektywność, ścisłość, bezosobowość, jasność (zrozumiałość), lakoniczność, dokładność, nieemocjonalność, ekspresywność (typu intelektualnego), nieprzystępność, łatwa przekładalność" (Mikołajczyk 1990, s. 12). Cechy te wynikają z użycia określonych, konkretnych środków językowych, do których należy przede wszystkim właściwa dla danej dziedziny terminologia naukowa. Według Stownika terminologii przedmiotowej „termin” jest to znak językowy, mający postać wyrazu lub połączenia wyrazowego, wchodzącego w skład słownictwa specjalistycznego i jest przeciwstawiany znakom językowym języka ogólnego (Lukaszyn, Górnicz 2005). Terminy naukowe decydują o takich cechach tekstu naukowego jak intelektualność, ścisłość, logiczność, pojęciowość, ale także - nieprzystępność, gdyż są znane zajmującym się określoną dziedziną specjalistom, ale często są niezrozumiałe dla laików, nawet jeśli są specjalistami w innej dziedzinie. Ponieważ muszą być jednoznaczne, w tekstach naukowych niejednokrotnie natrafiamy na definicje wyjaśniające mniej znane czy też w różny sposób definiowane terminy oraz definicje terminów tworzonych przez samego autora po to, aby jego wypowiedź była jasna, dokładna i jednoznaczna. Oto przykład:

„Tekstem” nazywam konkretne mowne i pisemne wyrażenia językowe, wytworzone przez jakiegokolwiek mówcę-słuchacza w konkretnym akcie językowej komunikacji. Natomiast wyrażenia ,dyskurs” używam dla określenia interakcji komunikacyjnej realizowanej głównie za pomocą tekstów. Piszę ,głównie”, ponieważ czysto tekstowa komunikacja w rzeczywistości nie zachodzi. Dyskurs z punktu widzenia antropocentrycznej 
teorii języków ludzkich to posługiwanie się konkretnymi tekstami przez konkretnych uczestników konkretnej interakcji komunikacyjnej. Inaczej mówiąc to, co określam jako „dyskurs”, to interakcja realizowana przez konkretnych uczestników dyskursu za pomocą konkretnych tekstów. Każdy dyskurs jest językowym współdziałaniem przynajmniej dwóch osób (uczestników danej interakcji), ,rozgrywa się” pomiędzy (przynajmniej) dwoma podmiotami. (Grucza 2013, s. 131-132)

Aby posługiwać się terminologią naukową, studenci nie tylko muszą rozumieć definicje, ale także je tworzyć. Toteż struktury umożliwiające definiowanie: coś $(M)$ to $(j e s t)$ coś $(M)$; coś $(M)$ jest czymś $(N)$; coś $(M)$ nazywamy czymś $(N)$; coś $(M)$ określa się jako coś $(B)^{l}$ wprowadza się już na pierwszych lekcjach języka specjalistycznego. Obok tych struktur studenci poznają partykuły i związki frazeologiczne przyłączające człon wyjaśniający: czyli, innymi słowy, inaczej mówiąc.

Prezentując obcokrajowcom definicje polskich terminów specjalistycznych i omawiając zagadnienia leksykalne, należy zwrócić uwagę na te słowa z języka ogólnego, które w języku specjalistycznym zyskały nowe znaczenie, na fakt, że terminy te, choć jednoznaczne w obrębie języka humanistyki, mogą mieć zupełnie inne znaczenie w języku ogólnym lub innych językach specjalistycznych (por.: celownik - jako 3. przypadek polskiej deklinacji, jako przyrząd służący do celowania w broni palnej lub jako urządzenie w aparacie fotograficznym służące do ustalania granic fotografowanego obrazu i do oceny jego kompozycji ${ }^{2}$ ).

Kolejną ważną kwestią jest zwrócenie uwagi na wyrazy obcego pochodzenia i na to, że „W przypadku języków specjalistycznych słowotwórstwo bazuje głównie na zapożyczeniach z języków klasycznych - głównie łaciny, w ostatnich czasach nowe dziedziny opierają się również na językach nowożytnych (głównie na języku angielskim)" (Sawicka 2009, s. 192). Istotną cechą terminów naukowych jest substantywizacja, toteż lektor uczący języka polskiego powinien zapoznać słuchaczy z mechanizmami derywacji rzeczowników. Znaczenie rzeczowników często modyfikowane jest przez przydawki (przedmiot badań, drogocenny przedmiot; praca organiczna, praca ze śniacym ciałem; teoretyczne podstawy wychowania; psychologia skierowana na proces), a czasowników przez dopełnienia (badać zagadnienie, analizować materiat, przeprowadzić ankietę) czy okoliczniki (leżeć u podstaw, wynikać z przeprowadzonych analiz). W takich wypadkach zwracamy uwagę na łączliwość wyrazów, np. możemy porozmawiać o metodach pracy, nauczania czy metodach wychowania, ale o sposobach zachowania; możemy też przeprowadzić badania, wnikliwa analize, ankietę czy wywiad, ale wyprowadzić wzór, wniosek, ewentualnie rodowód.

Znajomość kolokacji jest niezwykle ważna dla prawidłowego rozumienia artykułów naukowych czy treści wykładów uniwersyteckich. Związki frazeolo-

\footnotetext{
${ }^{1}$ Litery to skróty nazw przypadków gramatycznych: $\mathrm{M}$ - mianownik, $\mathrm{N}$ - narzędnik, $\mathrm{B}$ - biernik.

${ }^{2}$ Definicje słowa „celownik” wg Szymczak 1978. Słownik ten podaje sześć znaczeń słowa „celownik".
} 
giczne wraz z precyzyjnymi terminami decydują o jasności, ścisłości, dokładności tekstów akademickich. Istotną cechą tych tekstów jest także wspominana wcześniej obiektywność. Autorzy tekstów naukowych rzadko używają jako podmiotu formy pierwszej osoby liczby pojedynczej ,ja”. Mogłaby ona sugerować wyrażanie osobistej, indywidualnej, prywatnej opinii, a zatem brak obiektywizmu. Wyrażając opinię, tworzy się więc zdania bezpodmiotowe, a osoba autora znika za nieosobową formą orzeczenia: uznano, zaakceptowano, sądzi się, uważa się. Form nieosobowych używa się, opisując poszczególne fazy procesu badawczego: odkryto, opisano, prowadzi się badania czy opisując przedmiot lub wyniki badań: obserwuje się, wyróżnia się, przyjmuje się.

Aby nadać tekstom obiektywny, bezosobowy charakter w zdaniach podrzędnych wprowadza się orzeczenie wyrażane bezokolicznikiem: aby wyjaśnić; gdyby przyjać, że. Często używa się czasowników modalnych w formie bezosobowej: można / by / byto; powinno się, trzeba; warto podkreślić, należy powiedzieć, wystarczy przypomnieć. Obserwuje się dużą liczbę orzeczeń nominalnych: jest prawda, jest błędem i nierzadko w funkcji predykatywnej występuje rzeczownik „brak”: brak podstaw, aby; nie brak dowodów na poparcie tej tezy. Konstrukcje bezosobowe typu: jak / wiadomo, jest prawda, jest oczywiste - wprowadzają podmiot ogólny. W tego typu zdaniach nawet elementy wartościujące i oceniające wydają się być powszechnie panującymi, ogólnie akceptowanymi sądami. Bezosobowość tekstów naukowych jest więc cechą wskazującą na ich obiektywność. Jeżeli autor chce użyć podmiotu w formie osobowej, używa on zwykle formy 3. osoby - Autor tego opracowania uważa; Autorzy tej pracy sa zgodni, co do tego $\dot{z} e$... . Z kolei częste użycie pluralis modestiae jest próbą zaangażowania czytelnika do współpracy, uczynienia z niego partnera lub utożsamienia go z autorem: jak zauważyliśmy wcześniej; spójrzmy na to zagadnienie z innej strony. W tekstach popularnonaukowych zdarza się, że autorzy zwracają się do czytelników w 2. osobie: zdziwisz się zapewne czytelniku; zapytacie pewnie.

Kolejnym zabiegiem podkreślającym nieemocjonalność i obiektywizm jest częste użycie imiesłowów oraz strony biernej. S. Mikołajczyk pisze, że „użycie strony biernej wiąże się z tym, że podmiot opisu jest bardzo często pozaosobowy, a nawet opisy zachowań ludzi (socjologia, psychologia, pedagogika, historia, archeologia) są ujmowane pozaosobowo - w sposób uogólniony, skategoryzowany, a nie personalny; ważny jest przy tym przedmiot opisu, a nie autor opisujący. Strona bierna pozwala usunąć się badaczowi na dalszy plan - napisze on raczej: Badania sa kontynuowane, a nie: Naukowcy kontynuuja badania (Mikołajczyk 1990, s. 115).

O wiele częstsze niż w języku potocznym użycie wszystkich rodzajów imiesłowów pogłębia intelektualizm naukowych tekstów humanistycznych. Imiesłowy pojawiają się przy opisie przebiegu procesu badawczego, stosownych metod i procedur badawczych, przyjętych lub odrzuconych aspektów zagadnienia, prze- 
biegu wnioskowania (analizując, opierając się na, przyjąwszy za, pracujący nad, określony, badany, obserwowany). Przy charakterystyce opisywanych obiektów (namalowane, błyszczace) lub opisie relacji między obiektami (połaczone, wykluczone) obserwuje się przewagę imiesłowów biernych.

Tekstom naukowym właściwe są długie i rozbudowane zdania. Zdania pojedyncze bywają długie przede wszystkim wtedy, gdy zawierają wyliczenia. Te mogą być ponumerowane, wyróżnione myślnikiem lub literą alfabetu.

Najważniejsze tezy wyjściowe teorii antropocentrycznej, dotyczące wiedzy w ogóle przedstawiają się następująco:

a) wiedza stanowi pewną specyficzną właściwość wszystkich istot żywych, nie tylko ludzi, ale także zwierząt i roślin;

b) żadna wiedza nie jest bytem, żadna wiedza nie istnieje samodzielnie, a jedynie w połączeniu z posiadającym ją podmiotem;

c) wiedza to w szczególności pewne właściwości ludzkich i zwierzęcych mózgów. (Grucza 2013, s. 115)

Człony wyliczenia mogą poprzedzać też przydawki typu: nastęujące, takie (jak), poniższe, niżej wymienione. Wyliczenia występują zwykle w tekstach opisowych lub w częściach tekstu zawierających podsumowanie omówionych wcześniej treści. Dominują w nich relacje przydawkowe, a obok najczęściej występujących przydawek rzeczownych i przymiotnikowych występują przydawki imiesłowowe. Przydawki zaimkowe i liczebne spotyka się nieco rzadziej.

$W$ epoce brąu na tle ogólnego postępu w życiu gospodarczym i społecznym uksztattowaty się dwie, wyrastające z pnia indoeuropejskiego grupy etniczne, mianowicie już w I okresie epoki brazu plemiona nazywane wenetyjskimi na zachodzie, a w II okresie brąu plemiona neuryjskie na wschodzie ziem polskich. (Topolski 1975, s. 46).

Jak widać w powyższym przykładzie, przydawki imiesłowowe powodują wydłużenie zdań. Mają charakter czasownikowy, dzięki czemu mogą przyłączyć więcej określeń niż przydawki przymiotnikowe. Określenia przydawek imiesłowowych to najczęściej dopełnienie albo dopełnienie i okolicznik. Wydłużenie zdań mogą powodować też przydawki rzeczowne (wyrażone rzeczownikami abstrakcyjnymi, często odczasownikowymi).

Język artystyczny stanowi jedna z odmian wspótczesnej polszczyzny. Charakteryzuje się duża różnorodnościa, bywa często określany jako wlasność literatury pięknej będącej sztuka slowa. (Czernek 2011)

Cechą tekstów naukowych jest częsta obecność wypowiedzeń w nawiasach oraz wypowiedzeń wtrąconych, a przede wszystkim duża frekwencja zdań wielokrotnie złożonych. To także pogłębia stopień intelektualizacji i trudności tekstu, ale jednocześnie wzmacnia precyzyjność, dokładność i wyrazistość wypowiedzi. W naukowych tekstach humanistycznych spotykamy więc parataksy łączne, rozłączne, przeciwstawne i włączające. Obserwuje się jednak przewagę konstrukcji hipotaktycznych (przydawkowych, dopełnieniowych, okolicznikowych, rzadziej podmiotowych). Wypowiedzenia dopełnieniowe z członami: powiedział, że / 
żeby; twierdzi, że; sądzi, że wskazują na myślenie, mówienie, ocenianie. Podobną funkcję pełnią konstrukcje ze spójnikiem jak: jak już wspomniano, jak ustalono; jak dowiedziono. W zdaniach wielokrotnie złożonych pojawiają się podwójne wskaźniki zespolenia: że gdyby; że skoro; iż jeśli; który jak; co pomimo że, z których pierwszy odnosi się do zdania bezpośrednio, a drugi - do pośrednio podrzędnego. S. Mikołajczyk napisał „Wrażenie trudności, skomplikowania, dużej złożoności wypowiedzeń złożonych w tekstach naukowych jest następstwem nakładania się kilku faktów: trudności merytorycznej treści wypowiedzenia, jego ogólnej długości, długości wypowiedzeń składowych i niekiedy dodatkowo pewnych koniecznych dopowiedzeń (zawierających np. uwarunkowania, przyczyny, przesłanki) rozrywających linearnie któreś wypowiedzenie składowe, a przez to oddalające od siebie składniki, które się składniowo i semantycznie warunkują; poza tym hipotaktyczność wypowiedzeń złożonych przeplata się z hipotaktycznością wypowiedzeń składowych, czemu na ogół towarzyszy często wielowyrazowa terminologia. W sumie daje to wrażenie bardzo skomplikowanej składni zdania złożonego" (Mikołajczyk 1990, s. 175). Np.:

Ze swoistościa nauki w planie poznawczym (metodologia postępowania badawczego $i$ zasady budowy wiedzy), aksjonormatywnym (wartości i normy etosu), kulturowym (funkcje nauki: poznawcza oraz technologiczna, światopogladowa i edukacyjna oraz tradycje konkretyzujace się $w$ zespołach przekonań takich, jak ideały, paradygmaty i indywidualne style poznawcze) oraz społecznym (społeczność naukowa ze swoimi instytucjami) wiąże się też osobliwość komunikacyjno-językowa, która jest przedmiotem uwagi nie tylko językoznawstwa, ale przede wszystkim całej XX-wiecznej filozofii: neopozytywizmu i szkoły filozofii analitycznej, hermeneutyki i postmodernizmu. (Gajda 1999, s. 18)

\section{POLSKI JEZZYK HUMANISTYCZNY W PRAKTYCE GLOTTODYDAKTYCZNEJ}

Przed nauczycielem uczącym przyszłych humanistów stoi niełatwe zadanie doboru tekstów służących prezentacji materiału merytorycznego, gramatycznego i leksykalnego. Teksty te powinny być użyteczne zarówno dla kulturoznawców czy pedagogów, jak i dla adeptów innych nauk humanistycznych. Zadania takiego podjęły E. Bajor i E. Madej - autorki podręcznika Wśród ludzi i ich spraw (2006), a następnie E. Bajor i E. Sabela - autorki Zeszytu ćwiczeń (2010) do tego podręcznika. Podręcznik Wśród ludzi i ich spraw. Język polski dla cudzoziemców składa się z piętnastu jednostek lekcyjnych, z których każda omawia tematy aktualne i ważne dla współczesnego świata (np. edukacja, rodzina, stereotypy i uprzedzenia), mające znaczenie nie tylko dla humanistów, ale dla każdego, komu bliskie są sprawy kondycji człowieka we współczesnym świecie. Każda jednostka lekcyjna dzieli się na kilka segmentów, zawierających ćwiczenia rozwijające płynność 
mówienia, ułatwiające zrozumienie tekstów czytanych i słuchanych, ćwiczenia leksykalne i gramatyczne oraz takie, które pomagają w redagowaniu tekstów pisanych. Została uzupełniona Zeszytem ćwiczeń, który zawiera ćwiczenia leksykalne, gramatyczne, słowotwórcze oraz sprawdzające rozumienie tekstów pisanych do każdej z piętnastu jednostek lekcyjnych podręcznika Wśród ludzi i ich spraw. Klucz znajdujący się na końcu Zeszytu ćwiczeń umożliwia samodzielną pracę studentów. Chociaż i podręcznik, i Zeszyt ćwiczeń powstawały z myślą o kandydatach na studia humanistyczne, mogą służyć nie tylko im. Przeznaczone są dla wszystkich, którzy osiągnęli średnio zaawansowany poziom języka polskiego, chcą kontynuować naukę języka polskiego i zainteresowani są tematyką humanistyczną.

Wieloletnie doświadczenie autorki tego artykułu uczy, że z każdą grupą studentów pracuje się inaczej, że zwykle jeden podstawowy podręcznik nie wystarcza, trzeba szukać innych materiałów - bardziej aktualnych, bardziej potrzebnych czy po prostu bardziej interesujących. Można zatem wspomagać się innymi podręcznikami (B. Ligara, Rendez-vous z kultura polską. Podręcznik języka polskiego dla humanistów; W. Śliwiński, To właśnie Polska. Podręcznik języka polskiego dla humanistów). Źródłem tekstów do wszelkiego rodzaju ćwiczeń jest też prasa, zarówno ta drukowana, jak i internetowa. Można wymienić tytuły: „Wiedza i Życie”, „Świat Wiedzy”, Prawo i Życie”, „Historia i Polityka” oraz wiele innych, bo oferta na rynku jest duża, a wybór konkretnych pozycji należy do nauczyciela. $\mathrm{W}$ grupach zaawansowanych dobrze jest korzystać z fragmentów podręczników akademickich (po odpowiednim opracowaniu, obudowaniu ćwiczeniami). Materiału do pracy ze studentami dostarcza również kinematografia polska. I tutaj trudno ustalić kanon filmów, jakie student powinien obejrzeć, ale można polecić Idę P. Pawlikowskiego czy Dekalog K. Kieślowskiego jako punkt wyjścia do dyskusji o problemach etycznych współczesnego człowieka, Sale samobójców Jana Komasy - film zwracający uwagę na problemy, wynikające z braku kontaktu rodziców z dziećmi, oraz ekranizacje dzieł literatury polskiej, którymi można wspierać się w pracy z przyszłymi literaturoznawcami. Nieocenionym źródłem materiałów edukacyjnych jest Internet - oprócz tekstów do czytania, filmów fabularnych i dokumentalnych, możemy tam znaleźć piosenki, audycje radiowe, obrazy i fotografie ilustrujące omawiane problemy i mogące stanowić pretekst do ćwiczeń w mówieniu. Pracując z materiałami internetowymi, omawiając zagadnienia stylistyczne, możemy z jednej strony zwrócić uwagę na takie cechy języka jak neutralność, zwięzłość i precyzję (Sawicka 1970), z drugiej - na barwność stylu czy nacechowanie emocjonalne wypowiedzi. Choć te ostatnie cechy nie są wymieniane wśród cech specyficznych akademickich odmian specjalistycznych, występują przecież w wypowiedziach zarówno artystów, jak i dziennikarzy, polityków, a nawet prawników, z którymi to wypowiedziami słuchacze SJPdC będą się stykać jako studenci, doktoranci, praktykanci czy stażyści. Internet jest obec- 
nie najłatwiej dostępnym źródłem materiałów do ćwiczenia czterech sprawności. Można z nim pracować w klasie, a studenci - indywidualnie lub w grupach - mogą korzystać z niego, wykonując zadania domowe. Jest rzeczą bardzo ważną, aby proces nauczania nie ograniczał się do czterech ścian klasy i do podręcznika, bo im bardziej zrozumiała staje się dla studenta otaczająca go rzeczywistość językowa, tym większe jest jego przekonanie, że nauka na kursie przynosi efekty, a to motywuje go do dalszej pracy. Źródłem materiałów do analizy językowej powinno być więc także najbliższe otoczenie studentów - wiszące na ścianach zakazy, nakazy i regulaminy, ulotki reklamowe czy plakaty informujące o wydarzeniach kulturalnych. Udział w wydarzeniach kulturalnych, uczestnictwo w dniach otwartych organizowanych przez większość uczelni, obecność na wybranych wykładach akademickich, spotkania i imprezy z udziałem polskich studentów i naukowców to pierwsze próby „zaistnienia” w polskiej rzeczywistości socjolingwistycznej.

\section{STRUKTURY JEZZYKOWE W TEKSTACH HUMANISTYCZNYCH}

Artykuł ten powstawał z myślą o kandydatach na studia humanistyczne oraz o tych wszystkich, którzy osiągnęli średnio zaawansowany poziom języka polskiego, chcą kontynuować naukę tego języka i zainteresowani są tematyką humanistyczną. Powstawał też z myślą o nauczycielach uczących przyszłych humanistów. Ma ich nie tylko wspomagać, ale także dyscyplinować, gdyż w ograniczonym czasie muszą wprowadzić studentów na poziom językowy minimum B2 i przygotować ich do funkcjonowania w przestrzeni nauk humanistycznych. Aby ułatwić im to zadanie, podaję wykaz struktur językowych najczęściej powtarzających się w tekstach o tematyce humanistycznej.

\section{STRUKTURY JĘZYKOWE I ICH FUNKCJE}

1. Prezentacja osób: ktoś (M) to jest ktoś (M); ktoś (M) jest kimś (N); kogoś (B) nazywamy kimś $(\mathrm{N})$

2. Definiowanie, identyfikowanie: coś (M) to jest coś (M); coś (M) jest czymś $(\mathrm{N})$; coś $(\mathrm{M})$ nazywamy czymś $(\mathrm{N})$

3. Określanie relacji między ludźmi/między obiektami: ktoś (M) przyjaźni się z kimś $(\mathrm{N})$; ktoś $(\mathrm{M})$ rozstaje się z kimś $(\mathrm{N})$; ktoś/coś $(\mathrm{M})$ kłóci się z kimś/czymś $(\mathrm{N})$; ktoś/coś $(\mathrm{M})$ współdziała z kimś/czymś $(\mathrm{N})$; ktoś $(\mathrm{M})$ zrywa stosunki z kimś $(\mathrm{N})$ 
4. Określanie przynależności do zbioru: coś (M) składa się z czegoś (D); coś (M) należy do czegoś (D); coś (M) jest elementem czegoś (D); coś (B) zalicza się do czegoś (D); coś (B) klasyfikuje się jako coś (B); coś (B) dzieli się na coś (B); ktoś (M) jest członkiem czegoś (D); coś (B) obejmuje coś (B); coś (M) występuje w czymś (Ms)

5. Wyrażanie zależności: coś (M) zależy od czegoś (D); istnieje zależność między czymś $(\mathrm{N})$ a czymś $(\mathrm{N})$; coś $(\mathrm{M})$ wiąże się z czymś $(\mathrm{N})$; coś $(\mathrm{M})$ opiera się na czymś (Ms); coś (M) wywiera wpływ na coś (B); coś (M) dotyczy czegoś (D)

6. Wyrażanie pochodzenia, źródla: coś (M) pochodzi od czegoś (D); coś (M) wywodzi się skądś/z czegoś (D); źródłem czegoś (D) jest coś (M)

7. Opis właściwości przedmiotów i zjawisk: coś (M) charakteryzuje się czymś $(\mathrm{N})$; cechą/właściwością czegoś (D) jest coś $(\mathrm{M})$; coś $(\mathrm{M})$ jest właściwością czegoś (D); coś (M) polega na czymś (Ms).

8. Wskazywanie podobieństw, analogii: coś (M) jest podobne do czegoś (D); istnieje podobieństwo między czymś $(\mathrm{N})$ a czymś $(\mathrm{N})$; coś $(\mathrm{M})$ jest jak coś $(\mathrm{M})$; coś (M) przypomina coś (B); podobnie jak; tak samo jak; zarówno..., jaki i ... .

9. Wskazywanie różnic, kontrastów: coś (M) różni się od czegoś (D); coś (M) jest inne niż coś (M); coś (M) jest przeciwieństwem czegoś (M); w przeciwieństwie do (D) ; inaczej niż; natomiast.

10. Określanie położenia obiektu w przestrzeni: u góry; w środku; z boku; za; przed; między.

11. Relacjonowanie wydarzeń $\mathbf{w}$ sekwencji czasowej: podczas; zanim; przed x laty; w latach; w x wieku/stuleciu; na przełomie x wieku/stulecia; x lat przed naszą erą.

12. Wyrażanie związków przyczynowo-skutkowych: coś (M) jest skutkiem czegoś (D); coś (M) jest przyczyną czegoś (D); coś (M) prowadzi do czegoś (D); coś (M) wywołuje coś (B); coś (M) powoduje coś (B); dlatego, że; więc; wobec tego, na skutek, w wyniku

13. Wyrażanie celu, zamiaru: celem czegoś (D) jest coś (M); robić coś żeby + bezokolicznik; robić coś w celu (D)

14. Wyrażanie warunku: warunkiem czegoś (D) jest coś (M); coś (M) dzieje się pod warunkiem, że...; gdyby...; jeżeli...

15. Określanie funkcji, przeznaczenia, zastosowania: coś $(M)$ zaspokaja coś (B); coś (M) służy do czegoś (D); coś (M) służy czemuś (C); coś (M) jest funkcją czegoś (D); używać/użyć czegoś (D) do czegoś (D), posługiwać/posłużyć się czymś (N), za/stosować coś (B) w czymś (Ms), z/robić coś (B) za pomocą czegoś (D)

16. Nazywanie czynności procesu badawczego: ktoś (M) bada kogoś/coś (B); ktoś (M) odkrywa kogoś/coś (B); ktoś (M) zajmuje się kimś/czymś (N); ktoś (M) pracuje nad czymś (N)

17. Wyrażanie zdolności, możliwości i ich braku: ktoś (M) jest zdolny do czegoś (D); ktoś (M) ma możliwość zrobienia czegoś (D); ktoś (M) nie/potrafi + bezokolicznik 
18. Wyrażanie konieczności lub jej braku: nie/trzeba; nie/należy; nie/powinno się + bezokolicznik

19. Wyrażanie nakazów i zakazów: zrób to; nie wolno/nie należy + bezokolicznik

20. Wyrażanie obawy, strachu, lęku : coś (M) zagraża komuś/czemuś (C); coś (M) jest skierowane przeciwko komuś/czemuś (C); coś (M) jest niebezpieczne dla kogoś/czegoś (D)

21. Wyrażanie poczucia bezpieczeństwa: coś (M) chroni kogoś/coś (B) przed kimś/czymś (N); coś (M) sprzyja komuś/czemuś (C); ktoś (M) ma prawo do czegoś (D)

22. Wyrażanie aprobaty i dezaprobaty: akceptować kogoś/coś (B); popierać coś; protestować przeciwko komuś/czemuś (C); sprzeciwiać się komuś/czemuś; przeciwstawiać się komuś/czemuś (C)

23. Wyrażanie sympatii i antypatii: lubić kogoś/coś (B); nienawidzić kogoś/czegoś (D); zachwycać się kimś/czymś (N)

24. Wyrażanie opinii: uważać, że; sądzić, że; twierdzić, że; według kogoś/ czegoś (D)...; zdaniem kogoś (D) ....

25. Uzasadnianie opinii. Argumentowanie: coś (M) jest dowodem na coś (B); coś (M) dowodzi czegoś (D); coś (M) wskazuje na coś (B)

26. Modelowanie wypowiedzi: chodziło o to, że ...; to za dużo powiedziane.; to przesada.

\section{PODSUMOWANIE}

Podsumowując rozważania zawarte w niniejszym artykule, należy raz jeszcze podkreślić, że przygotowujący się do studiów w Polsce uczestnicy specjalistycznych kursów językowych muszą posiąść nie tylko znajomość konkretnego materiału gramatycznego, odpowiedni zasób słownictwa ogólnego i specjalistycznego, ale też umiejętność sporządzania notatek. Jako studenci będą musieli bowiem słuchać ze zrozumieniem kursowych wykładów, a uczestnicząc w studenckich konferencjach i sympozjach także referatów. Zarówno podczas słuchania, jak i podczas lektury będą musieli więc sporządzać notatki. Będzie się od nich wymagać aktywnego uczestnictwa w zajęciach - zadawania pytań i odpowiadania na nie, uczestniczenia w dyskusjach, prezentowania własnych i cudzych poglądów, formułowania opinii i wniosków, argumentowania i obrony określonych punktów widzenia. Wreszcie studenci będą sami przygotowywać i wygłaszać referaty, przygotowywać prezentacje naukowe, pisać prace semestralne i dyplomowe. Podczas kursów przygotowujących do studiów powinni więc, pracując samodzielnie, w parach lub w zespole, rozwinąc cztery podstawowe sprawności językowe - słuchanie, mówienie, czytanie i pisanie - w takim stopniu, aby mogli sprostać wymienionym wyżej zadaniom. 


\section{BIBLIOGRAFIA}

Bajor E., Madej E., 2006,Wśród ludzi i ich spraw. Język polski dla cudzoziemców, Łódź.

Bajor E., Sabela E., 2010, Zeszyt ćwiczeń do podręcznika , Wśród ludzi i ich spraw”, Łódź.

Czarnecka U., Gaszyńska M., 1990, Zrozumieć Polskę. Ćwiczenia w czytaniu dla studentów zaawansowanych, Kraków.

Czarnecka U., Gaszyńska M., 1992, Polubić Polskę. Ćwiczenia w czytaniu dla studentów zaawansowanych, Kraków.

Dobrowolska D., 2016, Metodyka edukacji polonistycznej w okresie wczesnoszkolnym, Kraków.

Gajda S., 1999, Język w naukach humanistycznych, w: W. Pisarek (red.), Polszczyzna 2000. Orędzie o stanie języka na przełomie tysiącleci, Kraków, s.12-32.

Gulczyński M., 2007, Nauka o polityce, Warszawa.

Ligara B., 1990, Rendez-vous z kultura polską. Podręcznik języka polskiego dla humanistów, Kraków.

Lukszyn J., Górnicz M., 2005, Języki specjalistyczne: słownik terminologii przedmiotowej, Warszawa.

Mikołajczyk S., 1990, Składnia tekstów naukowych. Dyscypliny humanistyczne, Poznań.

Śliwiński W., 1991, To właśnie Polska. Podręcznik języka polskiego dla humanistów. Kurs dla zaawansowanych, Kraków.

Topolski J. (red.), 1975, Dzieje Polski, Warszawa.

Stownik języka polskiego PWN, 1987, pod red. M. Szymczaka, Warszawa.

Wójcikiewicz M., 1993, Piszę, więc jestem. Podręcznik kompozycji i redakcji tekstów, Kraków.

Zieliński M., 1999, Języki prawne i prawnicze, w: W. Pisarek (red.), Polszczyzna 2000. Orędzie o stanie języka na przełomie tysiącleci, Kraków, s. 50-74.

Zylbertal W. H., 2002, Zintegrowany program humanistyki, w: E. Białek (red.), Dokąd zmierzasz człowieku? Model edukacji dla przyszłości, Warszawa, s. 167-176.

\section{ŹRÓDŁA INTERNETOWE}

Czernek P., 2011, Analiza składniowa i literalna grup nominalnych $w$ języku poetyckim Zbigniewa Herberta, http://www.moscice.pl/moje-moscice/blogi/blog-postscriptum/analiza -sk\%C5\%82adniowa-i-literalna-grup-nominalnych-w-j\%C4\%99zyku-poetyckim-zbigniewa -herberta/ [04.05.2016].

Grucza S., 2013, Lingwistyka języków specjalistycznych,w: S. Grucza i in. (red), Studi@ Naukowe 3, Warszawa, https://portal.uw.edu.pl/documents/7732735/0/Sambor+Grucza++Lingwisty$\mathrm{ka}+\mathrm{j} \% \mathrm{C} 4 \% 99 \mathrm{zyk} \% \mathrm{C} 3 \% \mathrm{~B} 3 \mathrm{w}+$ specjalistycznych.pdf. [27.04. 2016].

Sawicka A., 2009, Krótka charakterystyka języków specjalistycznych, w: „Rozprawy i Artykuły. Komunikacja Specjalistyczna", nr 2, http://www.ks.uw.edu.pl/KS2_001-295.pdf. [30.04.2016].

Wilkoń A., 1987, Typologia odmian językowych wspótczesnej polszczyzny, Katowice, http://www. sbc.org.pl/dlibra/plain-content?id=73129. [04.05.2016]. 


\section{Ewa Sabela-Dymek}

\section{POLISH FOR LESS AND MORE ADVANCED HUMANISTS}

Keywords: specialized language, Polish for humanities, features,texts, terminology, syntax

Summary. Taking into account the tasks that foreign students at Polish universities face, the author attempts to discuss those language characteristics that are common for various domains in the humanities and which make Polish for humanities particular. She draws attention to the properties of the language in academic and popular science texts (objectivism, intellectualism, or depersonalization) and discusses the linguistic means used for their creation. She points out the linguistic aspects which foreigners who intend to study in Poland should get familiarized with. She also discusses the sources of texts used for working with the students who attend professional language courses, ranging from academic textbooks (for the most advanced) to the media and online texts and textbooks for foreigners. 